\title{
First record of the Andean-mountain cavy Microcavia niata (Caviidae, Rodentia) from Peru
}

\section{Primer registro del cuy del Altiplano Microcavia niata (Caviidae, Rodentia) para Perú}

\author{
Horacio Zeballos ${ }^{1,2}$, Alexander Pari ${ }^{2}$, Kateryn Pino ${ }^{2,3 *}$, César E. Medina ${ }^{2}$, Joel Córdova ${ }^{4}$ \& \\ ROBERTO QUISPE ${ }^{2,5}$
}

\author{
${ }^{1}$ Instituto de Ciencias de la Naturaleza, Territorio y Energías Renovables; Pontificia Universidad Católica del Perú, Av. \\ Universitaria 1801, San Miguel, Lima 32, Perú. \\ ${ }^{2}$ Colección Científica, Museo de Historia Natural de la Universidad Nacional San Agustín (MUSA), Av. Alcides Carrión s/n, \\ Arequipa, Perú. \\ ${ }^{3}$ Programa de Doctorado en Sistemática y Biodiversidad, Departamento de Zoología, Facultad de Ciencias Naturales y \\ Oceanográficas, Universidad de Concepción, Casilla 160-C, Concepción, Chile. \\ ${ }^{4}$ Universidad Nacional Jorge Basadre Grohmann de Tacna, Av. Miraflores s/n, Tacna, Perú. \\ ${ }^{5}$ Santuario Histórico de Machu Picchu, SERNANP, Av. Oswaldo Baca N 402, Cusco, Perú. \\ *Email: katerynpino@udec.cl
}

\begin{abstract}
We report for the first time the presence of the Andean-Mountain Cavy, Microcavia niata, in Peru, being a new genus and species for Peruvian wildlife. We base our report on two specimens found in the highlands of Tacna, southwestern Peru.
\end{abstract}

\section{RESUMEN}

Reportamos por primera vez para el Perú al Cuy del Altiplano, Microcavia niata, la cual representa un nuevo género y especie para la fauna silvestre del Perú. Basamos este reporte en dos ejemplares encontrados en las tierras altas de Tacna, suroeste de Perú.

The South American rodents of the subfamily Caviinae (Ctenohystrica, Caviomorpha) are generally well-studied species (Dunnum \& Salazar-Bravo 2009, 2010, Ojeda 2006, Spotorno et al. 2004, Rood 1970, 1972, Cabrera 1953, 1961, Lacher 1981), although there are still some gaps in the biology and distribution knowledge of some species.

The Caviinae from Peru is represented by two genera Cavia and Galea (Dunnum 2015, Pacheco et al. 2009, Woods \& Kilpatrick 2005). The genus Cavia with three species: Cavia aperea Erxleben, 1777 of the Pampas del Heath (Medina et al. 2016, Romo et al. 2002); Cavia tschudii Fitzinger, 1857 in the Andean and coastal regions from Cajamarca to Tacna, with at least nine subspecies (Dunnum \& Salazar-Bravo 2009, 2010, Osgood 1913, 1914, 1919, Thomas 1917, 1926, 1927, Sanborn 1949); and the domestic form Cavia porcellus Linnaeus, 1758 (Dunnum \& SalazarBravo 2009, 2010, Chuca 1997, Spotorno et al., 2004, 2007). Galea with only one species, G. musteloides, in the southern highlands between Tacna and Puno departments (Osgood 1916, Pearson \& Ralph 1978, Solmsdorff et al.
2004, Dunnum \& Salazar-Bravo 2010). In this study we report for first time the record of Andean Mountain Cavy, Microcavia niata (Thomas, 1898) in Peru, based on two specimens from the highlands of Tacna, southernmost Peru, which were determined in the basis of their diagnostic characters (Dunnun 2015, Anderson 1997, Quintana 1996, Marquet et al. 1993, Cabrera 1953) and by comparison with Chilean specimens housed at the collection Patricio Sánchez Reyes Museum of the Pontificia Universidad Católica de Chile (PSR).

We collected two specimens of small cavy, as part of a faunal inventory of terrestrial small mammals in Conchaichiri, Province of Tarata, in Tacna Department, at southernmost of Peru, located to $17^{\circ} 17^{\prime} 18.73^{\prime \prime}$ S and $69^{\circ} 42^{\prime}$ 47.19 “W, 4230 m.a.s.l. (Figure 1). Conchaichiri belongs to the Puna Biogeographical Province (Morrone 2014), which is characterized by the presence of the Andean bog (known as "bofedales"), dominated by Distichia muscoides. Further, a great extension of puna grass and sparse cushion plants dominate the landscape, especially Pycnophyllum molle; 
also Werneria spp. Senecio humillimus, Azorella compacta, also Notothriche argentea, $N$. foetida, $N$. alternata, Astragalus peruvianus, Xenophyllum lycopodioides and Xenophyllum poposum. The soil is quite poor and eroded by overgrazing and harsh climate.

These specimens are deposited at the Scientific Collection associated with the Museo de Historia Natural de la Universidad Nacional de San Agustín (MUSA), under the numbers: MUSA 8744 and MUSA 16326.

Our specimens, an adult female (MUSA16326) and a juvenile (MUSA8744) show all the diagnostic characteristics described for Microcavia niata (Dunnum 2015, Anderson 1997, Thomas 1898, Quintana 1996, Marquet et al. 1993, Cabrera 1953). They are smaller compared with Cavia tschudii and Galea musteliodes (Table 1). Our specimens differ from G. musteliodes for their pale and soft fur with yellowish overtones; for having their interramal area completely covered with hair; white incisors; and the bridge of zygomatic arch with the anteorbital edge fully formed by the maxilla (Figure 2). With respect to $C$. tschudii, the collected specimens are smaller, with the coat yellowish and hairs long and silky.
The coat of Peruvian specimens is pale yellowish gray; the dorsal hairs are tricolored with gray base, dark gray in the middle, and yellow tips. The hairs on the back are about 16 to $18 \mathrm{~mm}$. Cheeks, throat, and belly whitish with gray base. The hairs around the eyes are slightly paler, with eyelids and eyelashes black. The fur of the ears is black and creamy yellow, with long and abundant hairs at the base and inside the ears. Interraramal hairy. Tragus and antitragus have little development but are clearly visible. Hairs on legs creamy with long hair extending from the sides of the legs. The plants are bare and black with fine grains, except on the heel that is smooth. The skull (Figure 2) seen in profile is strongly convex, the outline most rounded than others Microcavia (Quintana 1996, Ellerman 1940, Thomas 1898); the width of the braincase relative to skull length is 0.51 (Table 1); rostrum short and wide; nasals shorts and wide, its width represents $60 \%$ of their length; zygomatic arch expanded and solid, with a delicate and thin interorbital branch of maxilla not completely separated by the lachrymal; interorbital wide; interparietal very wide; carotid and jugular foramen ovale separated; jugal with a postorbital process; palatine foramen is well developed and laterally located, without palatal posterior

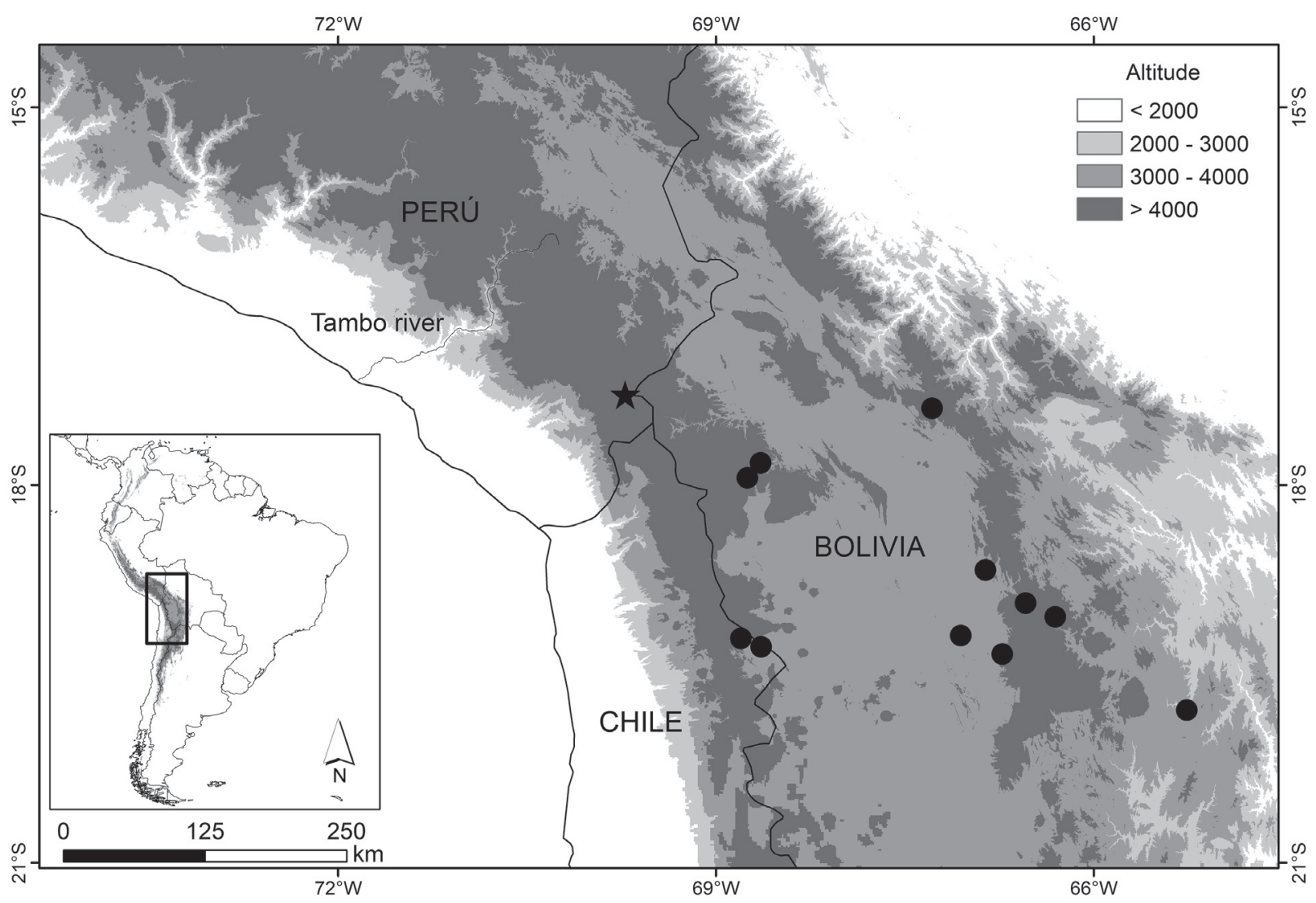

FiguRE 1. Known localities of Microcavia niata. Previous records (Thomas 1898, 1902; Anderson 1997; Marquet et al. 1993) (black circles). New record from Perú (black star). / Distribución conocida de Microcavia niata. Registros previos (Thomas 1898, 1902; Anderson 1997; Marquet et al. 1993) (círculos). Nuevo registro para Perú (estrella). 
flat expansion; posterior palatal margin is slightly angular; tympanic bullae inflated; superior molar length is greater than the diastema length; external flexus in upper molars non-developed; The upper cheek teeth are simple and do not have a fold back; P4 with additional prolongation developed; M3 with a short additional prism; Incisors completely white, narrow and orthodont; $m 3$ with additional prism large.

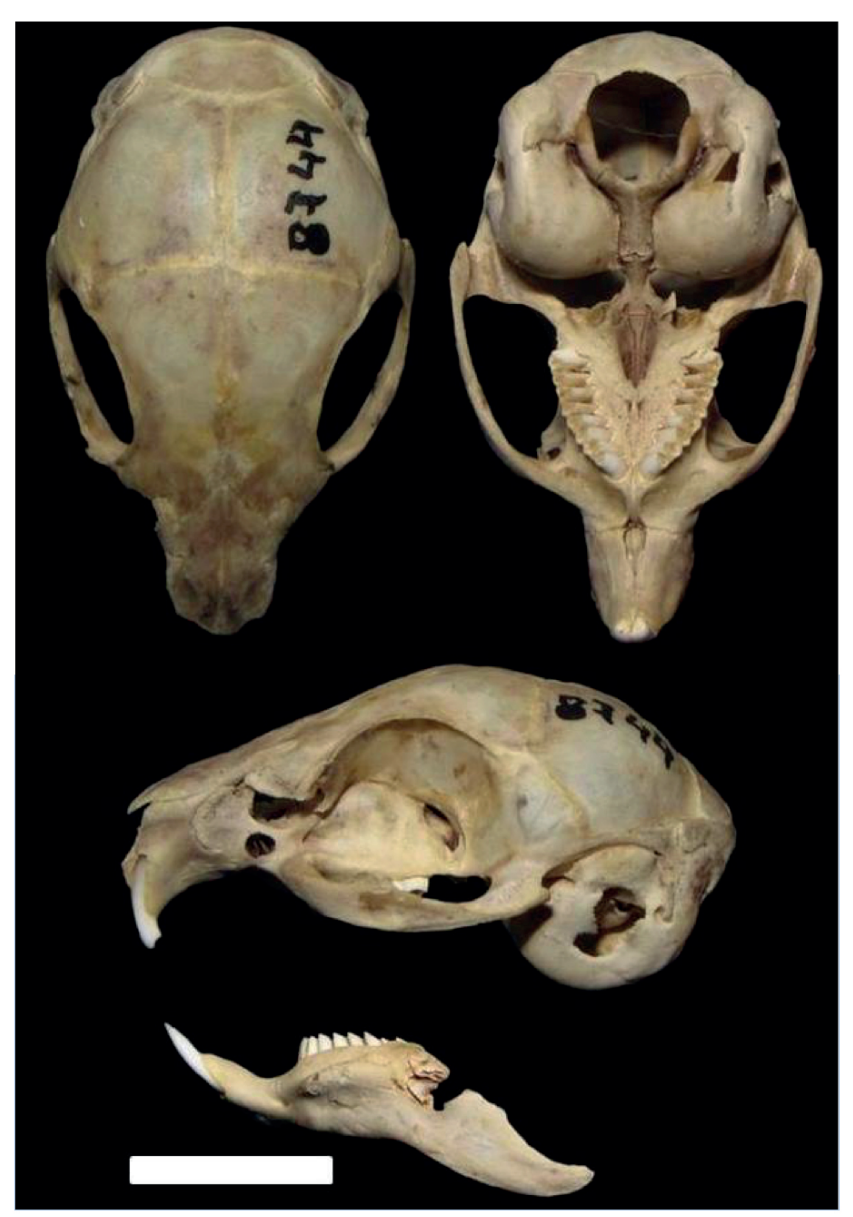

FIGURE 2. Dorsal, ventral, and lateral views of skull and lateral view of mandible of Microcavia niata (MUSA 8744) collected in Tacna, southwestern Peru. Scale bar $=10 \mathrm{~mm}$. / Figura 2. Vista dorsal, ventral y lateral del cráneo y vista lateral de la mandíbula de Microcavia niata (MUSA 8744), colectado en Tacna, al suroeste de Perú. Escala $=10 \mathrm{~mm}$.

Our comparative analyses confirmed that this species corresponds to Microcavia niata. Which turned out to be a new genus and species for Peru, extending its distributional range to $100 \mathrm{~km}$ from the type locality and Mount Sajama in Bolivia (Anderson 1997) and $230 \mathrm{~km}$ north of the Enquelga town in the Chilean Altiplano (Marquet et al. 1993). This would be the northernmost record of Microcavia niata distribution. The distribution of M. niata in Peru would include highlands localities in Tacna department and adjacent areas of southwestern of Puno department.

According to the distribution of the two subspecific forms described in this species, our specimen must match the nominal form Microcavia niata niata (Thomas 1898, 1902). Peruvian specimens present some notable traits in relation to Chilean material, its bigger interorbital, and interparietal regions, conditions present only in immature specimens of M. niata (Quintana 1996). Also, in relation to the orthodont condition of upper incisors of Peruvian sample, maybe a subadult condition, because of this may vary with the ontogenetic development as in M. robusta (Quintana 1996) or by geographic location like M. australis (Taraborelli et al. 2007), what should be related to the bow development of the skull.

The presence of M. niata in Peru was predicted by Pearson (1951) because the southeast area of the department of Tacna has similar environmental characteristics to the surrounding highlands of Chile and Bolivia as a continuous ecosystem until the Barroso Mountains, in Tacna. The biogeographical barrier which delimits the northern distribution of Puna's non-volant small mammals would be the Tambo river. In fact, several rodents species are delimited by this important geographical feature (i.e. Eligmodontia hirtipes, Galenomys garleppii, Ctenomys spp.) (Pearson 1982).

M. niata is one of the least known Caviidae, their descriptions have been quite poor and based on few specimens (Marquet et al. 1993, Anderson 1997). According to Marquet et al. (1993) is a gregarious species; this species and other cavies have been reported using abandoned burrows of Ctenomys (Marquet et al. 1993, Mann 1978, Pearson 1951), and could share burrows with other species (Juan Perez, unpublished data). This species appears to be associated with Andean bogs where it would find most of their food (Marquet et al. 1993). Their presence in Peru is notable because allow us to incorporate a new genus and species to Peruvian fauna, which now contains all living genera of Guinea Pigs of Subfamily Caviinae. In terms of conservation status we haven't information, however, appears to be a rare species in contrast to other guinea pigs and other rodents. These species depend on burrows from other species and Andean bogs with a reduced area for their refuge and food; maintains a range restricted to the highlands of Bolivia, Chile, and Peru, is located in an area that would be hard hit by water shortages in a climate change scenario and a growing mining. By these considerations should be considered as Vulnerable in Peru. However, it is necessary to increase the study focused on this species, and cavies in general, to improve this proposal and the knowledge of this important subfamily of charismatic rodents. 
TABLE 1. External and cranial measurements of Microcavia niata. Type specimens of M. niata niata $(*)$ and $M$. niata pallidior (**), deposited in the British Museum (BM), were taken from Thomas (1898, 1902). Measurements of the Sajama's specimens from Bolivia, were taken from Anderson (1987), deposited in the Field Museum (FMNH). Measures for Enquelga's specimens of Chile were obtained in the Patricio Sánchez Reyes Museum (PSR) at Pontificia Universidad Católica de Chile. All measurements in millimeters (mm). / TABLA 1. Medidas craneales y externas de Microcavia niata. Las medidas de especímenes tipo de M. niata niata (*) y M. niata pallidior (**), depositados en el British Museum (BM), fueron tomadas de Thomas (1898, 1902). Las medidas de los especímenes de Bolivia (Sajama), depositados en el Field Museum (FMNH) fueron tomadas de Anderson (1987). Las medidas de los especímenes de Chile (Enquelga), fueron obtenidos en el Museo Patricio Sánchez Reyes (PSR) de la Pontifica Universidad Católica de Chile.

\begin{tabular}{|c|c|c|c|c|c|c|c|c|c|}
\hline \multirow{3}{*}{ LOCALITY } & $\begin{array}{c}\mathrm{BM} \\
1716^{*}\end{array}$ & $\begin{array}{c}\text { BM } \\
1642 * *\end{array}$ & $\begin{array}{c}\text { FMNH } \\
53658\end{array}$ & $\begin{array}{c}\text { FMNH } \\
53669\end{array}$ & $\begin{array}{c}\text { FMNH } \\
53671\end{array}$ & $\begin{array}{l}\text { PSR } \\
\mathrm{s} / \mathrm{n}\end{array}$ & $\begin{array}{c}\text { PSR } \\
\mathrm{s} / \mathrm{n}\end{array}$ & $\begin{array}{c}\text { MUSA } \\
8744\end{array}$ & $\begin{array}{r}\text { MUSA } \\
16326\end{array}$ \\
\hline & \multicolumn{5}{|c|}{ Bolivia } & \multicolumn{2}{|c|}{ CHILE } & \multicolumn{2}{|c|}{ PERU } \\
\hline & SAJAMA & Aullaga & & SAJAMA & & ENQT & ELGA & $\mathrm{TA}$ & \\
\hline Total length & 190 & 200 & & $170-190$ & & & & 119 & \\
\hline Hind foot length & 34 & 41 & & $30-35$ & & & & 31 & \\
\hline Ear length & 13 & 22 & & 20 & & & & 14 & \\
\hline Greatest skull length & & 46.5 & 40.6 & 41.2 & 40.6 & 42 & 40.1 & 35 & 41.71 \\
\hline Basal length & 36.6 & & & & & 40.1 & 39.4 & 30.5 & 35.69 \\
\hline Basilar length & 33.5 & 35.5 & 38.2 & 38.5 & 38.1 & 38.6 & 38.4 & 29.41 & 30.13 \\
\hline Skull width & & & 21.1 & 20.8 & 20.5 & 22.7 & 22.9 & 18.3 & 20.5 \\
\hline Skull deep & & & & & & 22.2 & 22.2 & 16.2 & 18.23 \\
\hline Nasal length & 15 & & & & & 15.7 & 16 & 13 & 13.53 \\
\hline Nasal width & 9.1 & & & & & 9.4 & 9.4 & 5.9 & 6.91 \\
\hline Diastema length & 9.3 & & & & & 9.6 & 10.1 & 7.4 & 9.48 \\
\hline Palatal length & 18.5 & & 19.4 & 18.7 & 18.9 & 19.7 & 19.9 & 13.1 & 16.99 \\
\hline Interorbital width & 11 & & 11 & 10.7 & 11.6 & 11.6 & 11.4 & 10.1 & 11.29 \\
\hline Zygomatic arch width & & 32 & 29.4 & 29.8 & 30.8 & 31.1 & 30.3 & 21 & 25.34 \\
\hline Incisors length & & & & & & 6.5 & 7.1 & 5.2 & 5.79 \\
\hline Incisors width & & & & & & 2.1 & 2.2 & 2.1 & 2.43 \\
\hline Molar length & 10.2 & 12 & & & & 11 & 10.4 & 8.3 & 9.84 \\
\hline Fourth molar width & & & & & & 12.6 & 11.4 & 10.6 & 12 \\
\hline Bullae length & & & & & & 11.7 & 11.7 & 11.1 & 12.16 \\
\hline Bullae width & & & & & & 8.7 & 8.3 & 7.5 & 8.86 \\
\hline Interbullar length & & & & & & 4.2 & 4.5 & 2 & 2.38 \\
\hline Mandibular length & & & & & & 34.4 & 35.2 & 23.4 & 35.25 \\
\hline
\end{tabular}

\section{ACKNOWLEDGEMENTS}

Our deepest thanks to Giovanni Aragon by providing the specimen of their collection and Hugo Zamora by the botanical data. To Eduardo Palma for allowing the review of the specimens of "Patricio Sanchez Museum" in the Pontificia Universidad Católica de Chile. We are especially grateful to Enrique Rodríguez-Serrano for their critical comments and suggestions on the manuscript. This study was partially supported by The Mohamed Bin Zayed Species Conservation Found (Number grant: 11252582). Also thanks to the Ministerio de Agricultura y Riego by permissions to collect specimens (R.D. 263 MINAGRI-
DGFFS/DGEFFS). K. Pino appreciates the support of EDPG LPR-161 project of Dirección de Investigación of Universidad de Concepción.

\section{RFERENCES}

Anderson, S. 1997. Mammals of Bolivia, Taxonomy and distribution. Bulletin of the American Museum of Natural History 231:1-651.

Cabrera, A. 1953. Los roedores argentinos de la familia Caviidae. Facultad de Agronomía y Veterinaria, Universidad de Buenos Aires, Escuela de Veterinaria, Pub 6:1-93. 
First record of Microcavia niata from Peru: ZeBallos, H. ET AL.

Dunnum, J.L., Salazar-Bravo, J. 2009. Molecular systematics, taxonomy and biogeography of the genus Cavia (Rodentia: Caviidae). Journal of Zoology Systematics Evolution Research 48(4):376-388.

Dunnum, J.L., Salazar-Bravo, J. 2010. Phylogeny, evolution, and systematics of the Galea musteloides complex (Rodentia: Caviidae). Journal of Mammalogy 91(1):243-259.

Dunnum, J.L. 2015. Family Caviidae G. Fischer, 1817. En: Patton, J.L., Pardiñas U.F.J., D'Elía G. (Eds) Mammals of South America, Volume 2 Rodents: 690-726. The University of Chicago Press, Chicago.

Ellerman, J.R. 1940. The families and genera of living rodents. II Familia Muridae. British Museum Natural History, London. xii +689 pp.

LACHER, JR. T.E. 1981. The comparative social behavior of Kerodon rupestris and Galea spixii and the evolution of behavior in the Caviidae. Bulletin Carnegie Museum of Natural History 17:1-71

ManN, G. 1978. Los pequeños mamíferos de Chile (marsupiales, quirópteros, edentados y roedores). Gayana Zoología 40:1342.

Marquet, P.A., Contreras, L.C., Silva, S., Torres-Murúa, J.C., Bozinovic, F. 1993. Natural history of Microcavia niata in the high Andean zone of northern Chile. Journal of Mammalogy 74:136-140.

Medina, C.E., Pino, K., Pari, A., Llerena, G., Zeballos, H., López, E. 2016. Mammalian diversity in the Savanna from Peru, with three new addictions from country. Papéis Avulsos de Zoologia 56(2):9-26.

Morrone, J.J. 2014. Biogeographical regionalisation of the Neotropical region. Zootaxa 3782:1-110.

OjedA, R.A. 2006. Familia Caviidae Waterhouse, 1839. En: Barquez, R.M., Díaz M.M., Ojeda R.A. (Eds) Mamíferos de Argentina: sistemática y distribución: 206-210. Sociedad Argentina para el Estudio de los Mamíferos, Mendoza.

Osgood, W.H. 1913. New Peruvian mammals. Field Museum of Natural History 10(9):93-100.

OsGOoD, W.H. 1914. Mammals of an expedition across northern Peru. Field Museum of Natural History 10(12):143-173.

OsGood, W.H. 1916. Mammals of the Collins-Day South American expedition. Field Museum of Natural History 10(14):199216.

Osgood, W.H. 1919. Names of Some South American Mammals. Journal of Mammalogy 1(1):33-36.

Pacheco, V.R., Cadenillas, R., Salas, E., Tello, C., Zeballos, H. 2009. Diversidad y endemismo de los mamíferos peruanos. Revista Peruana de Biología 13(1):103-106.

Pearson, O.P. 1951. Mammals in the Highlands of Southern Peru. Bulletin of the Museum of Comparative Zoology at Harvard 106:117-174.

Pearson, O.P. 1982. Distribución de pequeños mamíferos en el altiplano y los desiertos del Perú. En: Salinas, P. (Ed) Zoología Neotropical: Actas VIII Congreso Latinoamericano de Zoología: 263-284. Mérida.

Pearson, O.P. \& Ralph, C.P. 1978. The diversity and abundance of vertebrates along an altitudinal gradient in Peru. Memorias Museo Historia Natatural Javier Prado 18:1-97.

QuintanA, C.A. 1996. Diversidad del roedor Microcavia
(Caviomorpha, Caviidae) de América del Sur. Mastozoología Neotropical 3(1):63-86.

Romo, M., Luna, L., Cornejo-Farfán, A. 2002. Mamíferos encontrados en el Santuario Nacional Pampas del Heath durante la expedición del RAP de 1996. En: Montambault, J.R. (Ed) Informe de las evaluaciones biológicas Pampas del Heath, Perú; Alto Madidi, Bolivia y Pando, Bolivia. Rapid Assessment Program RAP: (Ed. 66-70. Bulletin of Biological Assessment $N^{\circ} 24$.

Rood, J.P. 1970. Ecology and social behavior of the desert cavy Microcavia australis. The American Midland Naturalist 83:415-454.

Rood, J.P. 1972. Ecological and behavioural comparisons of three genera of Argentine Cavies. Animal Behaviour Monographs 5:1-83.

SAnBorn, C.C. 1949. Cavies of southern Peru. Proceedings of the Biological Society of Washington 62:133-134.

Solmsdorff, K., Kock, D., Hohoff, C., Sachser, N. 2004. Comments on the genus Galea Meyen 1833 with description of Galea monasteriensis n. sp. from Bolivia (Mammalia, Rodentia, Caviidae). Senckenbergiana Biologica 84:137-156.

Spotorno, A., Valladares, J.P., Marín, J.C., Palma, R.E., ZuletA, C. 2004. Molecular divergente and phylogenetic relationships of chinchillids (Rodentia: Chinchillidae). Journal of Mammalogy 85(3):384-388.

Spotorno, A., Manríquez, G., Fernández, A., Marín, J.C., GonzÁlez, F., Wheeler, J. 2007. Domestication of guinea pigs from southern Peru - northern Chile wild species and their middle pre-columbian mummies. En: Kelt, D.A., Lessa E.P., Salazar-Bravo J., Patton J.L. (Eds) Quintessential Naturalist: Honoring the Life and Legacy of Oliver P. Pearson: 367-388. The University of California Publications in Zoology, California.

Taraborelli, P., Sassi, P., Giannoni, S. 2007. Registro morfoecológico de Microcavia australis (Caviidae, Rodentia) en la puna de la provincia de San Juan, Argentina. Mastozoología Neotropical 14(1):107-112.

Thомаs, O. 1898. On some new Mammals from the Neighbourhood of Mount Sahama, Bolivia. Annals and Magazine of Natural History 7:277-282

Thomas, O. 1902. On Mammals collected by Mr. Perry O. Simons in the Southern Part of the Bolivian Plateau. Annals and Magazine of Natural History 8:222-230

Thomas, O. 1917. Notes on the species of the genus Cavia. Annals and Magazine of Natural History 7:52-160

Thomas, O. 1926. The Goldman-Thomas expedition to Peru.III. On mammals collected by Mr. R. W. Hendes in the Chachapoyas region of north Peru. Annals and Magazine of Natural History 9:156-167.

Thomas, O. 1927. The Goldman-Thomas expedition to Peru.- VI. On mammals from the upper Huallaga and neighbouring highlands. Annals and Magazine of Natural History 9:594608.

Woods, C.A., Kilpatrick, C.W. 2005. Infraorder Hystricognathi. En: Wilson, D.E., Reeder D.M. (Eds) Mammal species of the world: A taxonomic and geographic reference. Third edition: 1538-1600. Johns Hopkins University Press, Baltimore.

Recibido: 20.04.2017

Aceptado: 14.03.2018 